\title{
Effect of Beta Carotene Incorporated Mineral-Vitamin Premix on Infertility in Infertile Crossbred Cattle
}

\author{
Dheeraj Kumar $^{1}$, Rajendra Kumar ${ }^{1}$, V. K. Paswan ${ }^{1}$, Shilpa Kumari ${ }^{2}$, \\ G. Singh ${ }^{2^{*}}$ and Bhimraj ${ }^{1}$ \\ ${ }^{1}$ Department of Animal Husbandry \& Dairying, Banaras Hindu University, \\ Varanasi (U.P.), India \\ ${ }^{2}$ DEE, Agriculture University, Jodhpur, India \\ *Corresponding author
}

\section{A B S T R A C T}

\section{Keywords}

$\beta$-carotene,

Crossbred cows and infertile

\section{Article Info}

Accepted:

20 November 2019

Available Online:

10 December 2019
Bovine fertility is affected by nutritional and non nutritional factors. The non nutritional factors include micro-climate of the stable, lay-out of the stable, hygiene and genetic manipulations. The most common cause of infertility in cattle is poor nutrition (Navarre et al., 2010). Minerals have a great impact on animal's reproductive physiology. Their imbalance causes various problems leading to lowered reproductive efficiency and resultant monetary loss to the dairy industry. Adequate micro minerals supplementation is required as most of the roughages, greens, concentrates and even most of commercial feeds available to Indian market are deficient in trace mineral elements. Often, correcting an imbalance in mineral levels can solve the nagging problem of infertility by improving reproductive performance and health with little additional cost (Kumar et al., 2011). The main source of vitamin A for ruminants is B-carotene which is available in abundant quantities from green foliage. In the intestinal mucosa, B-carotene is converted to vitamin A. The importance of B-carotene had been viewed solely as a source of vitamin A until 1955. Since then, stabilized vitamin A has become available for use in animal feeds and research has extended into the comparison between vitamin A and B-carotene. It was not until the 1970s that B-carotene was suspected to have effects independent of its role as a vitamin A precursor in bovine reproduction. The present study shows total 24 infertile crossbred cows were selected to induce oestrus taken for correction of an oestrosity with $\beta$ carotene incorporated vitamin-permix. Total 8 out of 24 animals exhibited oestrus symptom after the treatment. Among the animals received $\beta$-carotene incorporated vitamin-permix (treatment group) 50\% showed the oestrus symptoms. Among the animals under control $16.66 \%$ came into heat.

\section{Introduction}

Cattle occupy a unique role in human history, having been domesticated since at least the early Neolithic age. Archeozoological and genetic data indicate that cattle were first domesticated from wild aurochs (Bos primigenius) approximately 10,500 years ago. 
They must have been very valuable to early human settlements, for they quickly became ubiquitous across world cultures and are considered the oldest form of wealth. Cattle are dual-purpose animals, raised for both milk and draught purposes. Beta carotene is important for oestradiol synthesis, stimulation of progesterone synthesis and scavenging of free radicals during hormone production. Beta-carotene is a precursor for vitamin A and the importance of beta-carotene in bovine reproduction is equivocal. Recent investigations of beta-carotene and vitamin A have focused on ovarian function especially on luteal development, progesterone production and fertility. Its deficiency resulted in extended duration of oestrus, delayed ovulation, retarded development of corpus luteum and a higher incidence of ovarian cysts which led to low conception rates and abortions in early pregnancy (Jukola et al., 1996).

Plasma beta-carotene concentrations during the peripartum period may affect ovulation in the first follicular wave postpartum in dairy cows (Kawashima et al., 2009). Ovulation and pregnancy require high concentration levels of vitamin $\mathrm{A}$ in the follicle/CL.

Only beta-carotene plasma levels can modulate or determine Vitamin A concentration in the follicle/follicular fluid. Beta-carotene supplementation improves reproduction (Akar et al., 2006) and milk yield parameters (Arechiga et al., 1998).

The various nutritive factors that also adversely affect the oestrus cycle include nutritive deficiencies of calcium, phosphorus, copper, manganese, zinc, iron, total protein, cholesterol etc. Modie (1965) described the role of calcium in sensitising the tabular genetalia for the action of hormones. A very high percentage of calcium and phosphorus is located in the bone and most of these minerals can be mobilized when needed for use in the metabolic events of body tissue. Calcium and phosphorus are closely related to many metabolic events in the body (Jacobson et al., 1972).

\section{Materials and Methods}

\section{Place of work and Animals}

The study was planned and conducted on 24 cross-bred non-cyclic, non-pregnant cattle of B.H.U. dairy farm. Cattle, which were not observed in estrus for at least six months considered as non-cyclic animals.

On the basis of clinical observations, cattle affected with any kind of infectious causes or structural pathological abnormalities were excluded from the study.

\section{Selection of cattle}

\section{Breed}

Cattle were selected of same breed, all cattle are cross bred (sahiwal $\times$ H.F.).

Age

Age of all cattle was around 3-6 years.

\section{Body weight}

Body weight of all cattle around $350-500 \mathrm{~kg}$.

\section{Body condition}

Body condition of cattle is good muscular, attractive, shiny hair coat and active eyes.

\section{General management practices}

Management practices are the main determinant of the expression of natural behavioural patterns of the animals and any 
alteration of this natural behavioural patterns lead to health disorders. Managemental practices followed in the present study have been discussed in different heading as follows.

\section{Housing}

The experimental animals were maintained in loose housing system under group Management practice with proper drainage, soft bedding, feeding and watering facilities. The feeding mangers were covered with shed type roof consisting of asbestos sheets at moderate height with low slope.

At one corner of paddock, there was provision of drinking water trough with running tap water. The housing system is designed in such a way that it provides ample air movement and protects animals from extreme weather.

Feeding manger and watering trough was as per BIS standard. This system of housing facilitated free movement, sufficient exercise to the animals and the animals exhibit their natural behaviour.

\section{Feeding}

The nutrient requirements of all experimental animals were mostly met with adlibitum green fodder and measured amount of concentrate. The green fodders, grown in the Institute farm, were supplied according to the seasonal availability. During summer and rainy seasons predominantly maize and sorghum were fed whereas in winter, fodders like barseem, oat, were fed. Feedings were spread in 3 to 4 feeding during day and night. The concentrate was fed @ $1.5 \mathrm{~kg} /$ day/animal for body maintenance in general. Concentrate mixture had 20\% CP and 70\% TDN consisted of 33\% maize, $21 \%$ ground nut cake (oiled), $12 \%$ mustered cake (oiled) $20 \%$ wheat bran, $11 \%$ de-oiled rice bran, $2 \%$ mineral mixture and $1 \%$ common salt.

\section{Supplementation of feed}

Rovimix ovn dairy premix (DSM nutritional products)

\begin{tabular}{|l|l|}
\hline $\begin{array}{l}\text { Each 100g } \\
\text { contains }\end{array}$ & \\
\hline $\begin{array}{l}\text { Rovimix } \\
\text { vitamin-A }\end{array}$ & $2.000 \mathrm{MIU}$ \\
\hline $\begin{array}{l}\text { Rovimix } \\
\text { vitamin-D3 }\end{array}$ & $0.400 \mathrm{MIU}$ \\
\hline Vitamin-E & $20.000 \mathrm{MIU}$ \\
\hline Biotin & $0.400 \mathrm{gm}$ \\
\hline Niacin & $10.000 \mathrm{gm}$ \\
\hline Beta-carotene & $10.000 \mathrm{gm}$ \\
\hline Iron & $12.000 \mathrm{gm}$ \\
\hline Copper & $4.000 \mathrm{gm}$ \\
\hline Manganese & $15.000 \mathrm{mg}$ \\
\hline Zinc & $16.000 \mathrm{gm}$ \\
\hline Magnesium & $80.000 \mathrm{gm}$ \\
\hline Cobalt & $0.400 \mathrm{gm}$ \\
\hline Iodine & $0.300 \mathrm{gm}$ \\
\hline Selenium & $0.120 \mathrm{gm}$ \\
\hline Chromium & $0.500 \mathrm{gm}$ \\
\hline Potassium & $5.000 \mathrm{gm}$ \\
\hline Sodium & $6.000 \mathrm{gm}$ \\
\hline
\end{tabular}

\section{Dose}

50 gm Rovimix ovn dairy premix (DSM nutritional products) in evening

\section{Beta carotene assessment}

Blood samples were taken on day of the start of mineral supplement treatment, on 0 day and on 45 day, from jugular vein in sterilized collecting tubes. Tuberculin syringe was used to measure $400 \mu \mathrm{L}(0.4 \mathrm{~mL})$ of the fresh blood.

iCheck $^{\mathrm{TM}}$ Carotene (BioAnalyt Germany) a portable photometer (provided by DSM) 
was used to determine beta carotene concentrations. It determined total carotenoid concentration in the fresh blood samples by measuring the color reaction in the test vial and calculated the carotene content in $\mathrm{mg} / \mathrm{L}$.

\section{Collection of blood}

About $10 \mathrm{ml}$ of blood samples were drawn from the Jugular vern with $18 \mathrm{~g}$ sterilized needles from each animal, (both experimental and control). Blood samples were transferred immediately in dry, sterilized glass test tubes and kept at $45^{\circ} \mathrm{c}$ angle in room temperature after proper coding.

\section{Observations used for heat detection}

All the cows were checked and parameters like duration of onset of estrous post protocol, total duration of estrous and the signs of estrous like-restlessness and mounting behavior, discharge and its amount, bellowing and tonicity of uterus were recorded.

\section{Breeding}

All cows were artificially inseminated with frozen semen of high fertility.

\section{Statistical analysis}

The Data obtained during investigation were subjected to statistical analysis using independent t-test.

\section{Results and Discussion}

In treatment group, mean beta carotene level at day 0 i.e. before the start of the treatment, was $2.55 \pm 0.13 \mathrm{mg} / \mathrm{l}$. At day 45 of the treatment, the blood mean beta carotene levels rose to $3.31 \pm 0.17 \mathrm{mg} / \mathrm{l}$. Six cows showed oestrus. The day of showing oestrus ranged from day 8 to day 45 , with an average of 22 days.

In control group, mean beta carotene level at day 0 i.e., was $2.62 \pm 0.12 \mathrm{mg} / \mathrm{L}$. At day 45 , the blood mean beta carotene level 2.71 \pm 0.14 $\mathrm{mg} / \mathrm{L} .2$ cows showed oestrus. The day of showing oestrus ranged from day 16 to day 45 , with an average of 28 days.

Similarly Rakes et al., (1985) reported feeding $300 \mathrm{mg}$ beta carotene per head for 100 days resulting in improved reproductive parameters and Arechiga et al., (1998) showing better results after 90 days of feeding in comparison to 15 days of feeding beta carotene in diet.

One of the possible roles of the beta carotene is its antioxidant effect as reported by Arechiga et al., (1998). Moreover, Arechiga et al., (1998) reported higher fertility rates in beta carotene supplemented cows in another study. In the present study, beta carotene might have an antioxidant effect and, high beta carotene levels might show its antioxidant effect in pregnant cows. The overall mechanism of beta carotene is not clearly understood and there are still controversies about its effect on reproduction Halilogu et al., (2002). While work erssuchas Graveshoagland et al., (1989), Iwanska et al., (1997) and Akar et al., (2006) reported that beta carotene has a positive effect, there are also reports from Gossen et al., (2004, 2005) indicating it has no effect whereas Bindas et al., (1984) and Yildiz et al., (2005) reported negative effect of beta carotene on reproductive parameters in cows (Table 1-3 and Fig. 1).

\section{Summary}

In treatment group ( $\beta$-carotene incorporated vitamin-permix) 6 animals came into heat. Serum $\beta$-carotene, level was significantly higher (significant at 5\% level) in oestrus 
condition than in anoestrus condition in this group. In control group only 2 animals came into the heat. Here no parameter shows any significant change in between the anoestrus and oestrus condition.

The observations for 12 cows of treatment group, provided with mineral mixture with beta carotene supplementation:
The blood level of beta carotene rose from $2.71 \pm 0.14 \mathrm{mg} / \mathrm{L}$ at day 0 to $3.31 \pm 0.17$ $\mathrm{mg} / \mathrm{L}$ at day 40 of feed supplementation.

Beta carotene deficiency is responsible for anestrus in cows, beta carotene supplementation definitely improves the anoestrous condition with overall fertility.

Table.1 Treatment Group

\begin{tabular}{|c|c|c|c|}
\hline S.N. & TAG NO. & COW/HEIFER & AGE (yr.) \\
\hline $\mathbf{1}$ & 739 & HEIFER & 4 \\
\hline $\mathbf{2}$ & 729 & HEIFER & 3 \\
\hline $\mathbf{3}$ & 758 & HEIFER & 3 \\
\hline $\mathbf{4}$ & 920 & HEIFER & 4 \\
\hline $\mathbf{5}$ & 817 & COW & 5 \\
\hline $\mathbf{6}$ & 688 & HEIFER & 3 \\
\hline $\mathbf{7}$ & 757 & HEIFER & 4 \\
\hline $\mathbf{8}$ & 697 & HEIFER & 4 \\
\hline $\mathbf{9}$ & 815 & COW & 3 \\
\hline $\mathbf{1 0}$ & 704 & HEIFER & 3 \\
\hline $\mathbf{1 1}$ & 767 & HEIFER & 7 \\
\hline $\mathbf{1 2}$ & 726 & HEIFER & 3 \\
\hline
\end{tabular}

Table.2 Control Group

\begin{tabular}{|c|c|c|c|}
\hline S.N. & TAG NO. & COW/HEIFER & AGE (yr.) \\
\hline $\mathbf{1}$ & 672 & HEIFER & 4 \\
\hline $\mathbf{2}$ & 816 & COW & 5 \\
\hline $\mathbf{3}$ & 804 & COW & 6 \\
\hline $\mathbf{4}$ & 818 & COW & 5 \\
\hline $\mathbf{5}$ & 819 & COW & 6 \\
\hline $\mathbf{6}$ & 730 & HEIFER & 3 \\
\hline $\mathbf{7}$ & 910 & HEIFER & 6 \\
\hline $\mathbf{8}$ & 732 & HEIFER & 4 \\
\hline $\mathbf{9}$ & 701 & HEIFER & 4 \\
\hline $\mathbf{1 0}$ & 698 & HEIFER & 3 \\
\hline $\mathbf{1 1}$ & 755 & HEIFER & 4 \\
\hline $\mathbf{1 2}$ & 753 & HEIFER & 4 \\
\hline
\end{tabular}


Table.3 Status of beta carotene $(\mathrm{mg} / \mathrm{l})$ level in blood

\begin{tabular}{|c|c|c|c|}
\hline \multirow{2}{*}{ Days } & \multicolumn{2}{|c|}{ Mean \pm SE } & \multirow{2}{*}{ P-value } \\
\cline { 2 - 3 } & Control & Treatment & \\
\hline $\mathbf{0}$ & $2.62 \pm 0.12$ & $2.71 \pm 0.14$ & 0.326 \\
\hline $\mathbf{4 5}$ & $2.55 \pm 0.13$ & $3.31 \pm 0.17$ & 0.001 \\
\hline
\end{tabular}

Fig.1 Diagram showing the status of beta carotene $(\mathrm{mg} / \mathrm{l})$ level in blood

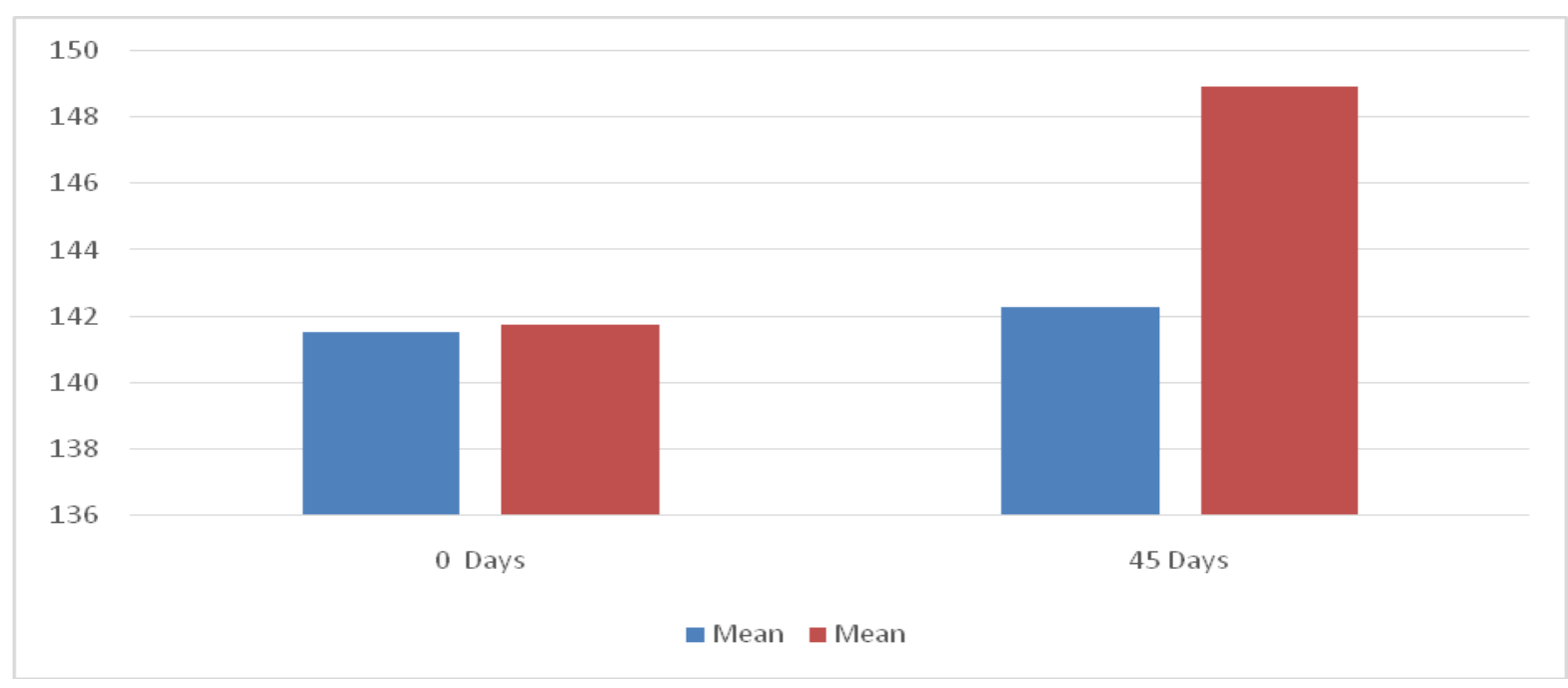

\section{References}

Anwandter, Q.C.G.(1974). Progesterone and $\beta$-Carotin-Gehalt des bovinen corpus luteum wahrend der verschiedenenphasen des sexualzyklus in abhangigkeit von der Jahreszeit (Doctoral dissertation, Dissertation, Tierarztl. Hochschule, Hannover).

Ganguly, J. and Sastry, P.S. (1985). Mechanism of conversion of Bcarotene into vitamin A-central cleavage versus random cleavage. In World Nutritional Determinants, (Vol. 45, pp. 198-220). Karger Publishers.
Kawashima, C., Kid, A.K., Schweigert, F.J. and miyamoto, A. (2009). Relationship between plasma betacarotene concentrations during the peripartum period and ovulation in the first follicular wave postpartum in dairy cows. Animal Reproduction Science, 111(1):105-111.

Ondarza, M.B.D.E., Wilson, J.W. and Engstrom, M. (2009). Effect of supplemental $\beta$ - carotene on yield of milk and milk components and on reproduction of dairy cows. Animal Reproduction Science, 25(4): 510516.

\section{How to cite this article:}

Dheeraj Kumar, Rajendra Kumar, V. K. Paswan, Shilpa Kumari, G. Singh and Bhimraj. 2019. Effect of Beta Carotene Incorporated Mineral-Vitamin Premix on Infertility in Infertile Crossbred Cattle. Int.J.Curr.Microbiol.App.Sci. 8(12): 2738-2743. doi: https://doi.org/10.20546/ijcmas.2019.812.320 